\begin{tabular}{|c|c|c|c|c|c|c|}
\hline \multirow{3}{*}{$\begin{array}{l}\text { 2. ECN Category } \\
\text { (mark one) } \\
\text { Suppl emental } \\
\text { Direct Revision } \\
\text { Change ECN } \\
\text { Temporary } \\
\text { Standby } \\
\text { Supersedure } \\
\text { Cancel/Void }\end{array}$} & \multirow{3}{*}{$\begin{array}{r}{[]} \\
{[x]} \\
0 \\
0] \\
0 \\
0 \\
0\end{array}$} & \multicolumn{2}{|c|}{$\begin{array}{l}\text { 3. Originator's Name, Organization, MSIN, } \\
\text { and Telephone No. } \\
\text { Pat J. Sullivan, 15540, T5-54, } \\
373-1788\end{array}$} & \multicolumn{2}{|c|}{$\begin{array}{l}\text { 3a. Uso Required? } \\
{[X] \text { Yes [] No }}\end{array}$} & $\begin{array}{l}\text { 4. Date } \\
6-11-96\end{array}$ \\
\hline & & \multicolumn{2}{|c|}{$\begin{array}{l}\text { 5. Project Title/No./Nork order No. } \\
\text { PFP Instrument Upgrade / B610 / } \\
\text { K6034 }\end{array}$} & \multicolumn{2}{|c|}{$\begin{array}{l}\text { 6. Bldg./Sys./Fac. No. } \\
\text { GENERAL/24A/PFP }\end{array}$} & $\begin{array}{l}\text { 7. Approval Designator } \\
\text { E S Q }\end{array}$ \\
\hline & & \multicolumn{2}{|c|}{$\begin{array}{l}\text { 8. Document Numbers Changed by th is ECN } \\
\text { (includes sheet no. and rev.) } \\
\text { WHC-SD-CP-SDD-006 REV } 1\end{array}$} & \multicolumn{2}{|c|}{$\begin{array}{l}\text { 9. Reloted ECN No(8). } \\
191556,607944\end{array}$} & $\begin{array}{l}\text { 10. Related PO No. } \\
\text { N/A }\end{array}$ \\
\hline \multirow{2}{*}{\multicolumn{2}{|c|}{$\begin{array}{l}\text { 11a. Modification Work } \\
\text { [] Yes (fill out Blk. } \\
\text { [X] No (MA Blks. 11b, } \\
11 \mathrm{c}, 11 \mathrm{~d})\end{array}$}} & \multirow[t]{2}{*}{$\begin{array}{l}\text { 11b. Work Package } \\
\text { Mo. } \\
\text { N/A }\end{array}$} & \multicolumn{2}{|c|}{$\begin{array}{l}\text { 11c. Modification Work Complete } \\
\text { N/A }\end{array}$} & \multicolumn{2}{|c|}{$\begin{array}{l}\text { 11d. Restored to Original Condi- } \\
\text { tion (Temp. or Standby ECM only) } \\
\text { N/A }\end{array}$} \\
\hline & & & \multicolumn{2}{|c|}{ Cog. Engineer Signature \& Date } & \multicolumn{2}{|c|}{ Cog. Engineer Signature \& Date } \\
\hline
\end{tabular}

12. Description of Change Desugn Basel,ne Docuwient: Yes

Changes are being made to reflect a new stack alarm system configuration following completion of Project B610. Stack alarms previously contained on alarm panels in Rooms 321-A/221-A of 234-5Z and Room 631 of 2736-ZB are being relocated to a new panel in Room 714 of 234-5ZA. Alarm enhancements are also being made. The new alarm panel will generate an alarm upon loss of continuity in alarm signal wiring. This alarm is being added to the list of safety envelope equipment and the wiring, which was previously safety envelope equipment, is being excluded from the safety envelope with this revision. Also, ganged loss of vacuum alarms from 291-Z-1 Stack are being separated into two distinct alarm signals. A statement was added regarding the acceptability of using the Record Sample for 2-hr checks. The safety envelope procedure section and drawing reference numbers were also updated to reflect the new configuration. Finally, ECN's referenced in Block 9 of this ECN are being incorporated into the new revision.

13a. Justification (mark one)
\begin{tabular}{llllllll} 
Criteria Change $[X]$ & Design Improvement & {[]} & Environmental & [] & Facility Deactivetion \\
As-Found & {[]} & Facilitate Const & {[]} & Const. Error/Omission & [] & Design Error/Onission \\
\hline
\end{tabular}

13b. Justification Details

For USQ Evaluation reference USQ * PFP-96-11 "MICON Control Room Panel Annunciator"

Revision required to support a new system configuration created by Project B610. Also, changes from outstanding ECN's referenced in Block \#9 are being incorporated.

14. Distribution (include name, MSIN, and no. of copies)

See Distribution Sheet Page 1.

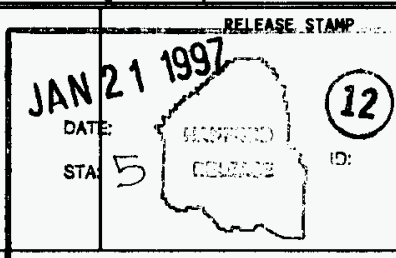




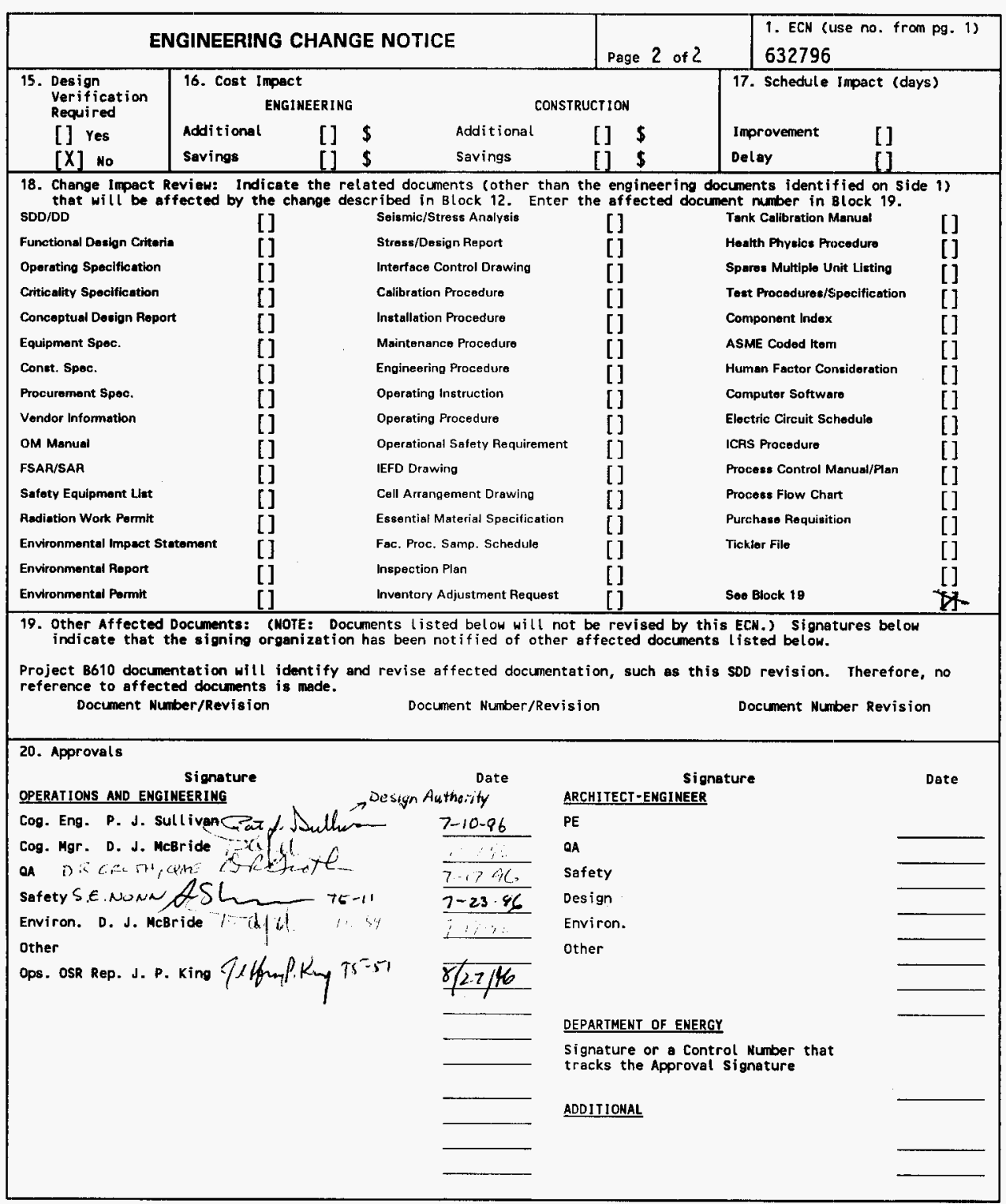




\title{
Definition and Means of Maintaining the Effluent Stack Monitors Portion of the PFP Safety Envelope
}

\author{
Pat J. Sullivan
}

Babcock \& Wilcox Hanford Company, Richland. WA 99352

U.S. Department of Energy Contract DE-AC06-87RL10930
EDT/ECN: 191556,607944 UC: 506
632796
Org Code: $15540 \quad$ Charge Code: K6058
B\&R Code: EW7002010 Total Pages: 27

Key Words: Stack Monitor, Continuous Air Monitor, Effluent, Authorization Basis, Safety Envelope, OSR. TSR. PFP FSAR

Abstract: The Effluent Stack Monitors ensure that the release of alpha emitting radionuclides to the environment via the building exhaust stacks is continuously monitored and alarms are initiated if the release exceeds identified limits. This document defines the safety envelope for the Effluent Stack Monitors and identifies the operability requirements, components, and procedures which ensure this safety envelope is maintained.

TRADEMARK DISCLAIMER. Reference herein to any specific comercial product, process, or service by trade name, trademark, manufacturer, or otherwise, does not necessarily constitute or imply its endorsement, recommendation, or favoring by the United States Government or any agency thereof or its contractors or subcontractors.

Printed in the United States of America. To obtain copies of this document, contact: WHC/BCS Document Control Services, P.O. Box 1970, Mailstop H6-08, Richland WA 99352, Phone (509) 372-2420; Fax (509) 376-4989.
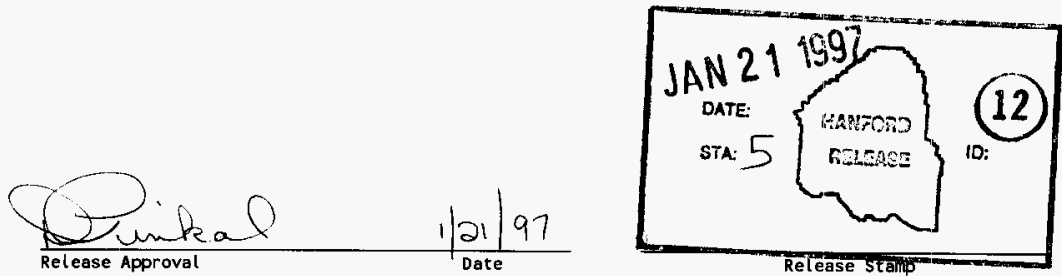

\section{Approved for Public Release}




\begin{tabular}{|c|c|c|c|c|}
\hline \multicolumn{2}{|r|}{ RECORD OF REVISION } & \multicolumn{2}{|c|}{$\begin{array}{l}\text { (1) Document Mumber } \\
\text { WHC-SD-CP-SDD-006 }\end{array}$} & Page 2 of 27 \\
\hline \multicolumn{5}{|c|}{$\begin{array}{l}\text { (2) Title } \\
\text { Definition and Means of Maintaining the Effluent Stack Monitors Portion of the PFP } \\
\text { Safety Envelope }\end{array}$} \\
\hline \multicolumn{5}{|c|}{ CHAMGE CONTROL RECORD } \\
\hline (3) Revision & (4) Description of Change - Replace, Add, and Delete Pages & \multicolumn{3}{|c|}{ Authorized for Release } \\
\hline 1 & $\begin{array}{l}\text { (7) This is a total rewrite; therefore, } \\
\text { revision bars have not been used to } \\
\text { indicate changes. ECN is } 166685 \text {. } \\
\text { WHC-SD-CP-SDD-005, Rev. O. EDT } 141527 \text {, } \\
2 / 11 / 93 \text {. }\end{array}$ & $\begin{array}{l}\text { (5) Cog. Engr. } \\
\text { original } \\
\text { signed by } \\
0 . \text { A1 ison } \\
10-6-93\end{array}$ & $\begin{array}{l}\text { (6) } c \\
\text { orig } \\
\text { by } D \\
12-6\end{array}$ & $\begin{array}{l}\text { Mgr. Oate } \\
\text { McBride } \\
\text { lat signed }\end{array}$ \\
\hline $\begin{array}{c}2 \\
R S\end{array}$ & $\begin{array}{l}\text { Incorporates changes presented in ECN's } \\
607944 \text { and } 191556 \text { and additional changes } \\
\text { required by Project B610. Total rewrite } \\
\text { per ECN } 632796 \text {. }\end{array}$ & 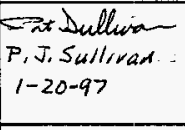 & $\sum_{1-2} \sin _{1-2}$ & Leb \\
\hline & & & & \\
\hline & & & & \\
\hline & & & & \\
\hline & & & & \\
\hline & & & & \\
\hline & & & & \\
\hline & & & & \\
\hline & & & & \\
\hline & & & & \\
\hline & & & & \\
\hline
\end{tabular}


Table of Contents

LIST OF ACRONYMS . . . . . . . . . . . . . . . . . . . 4

STACK \& BUILDING CROSS REFERENCE ............... 4

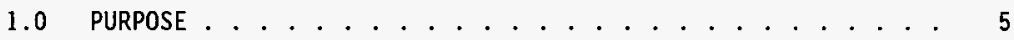

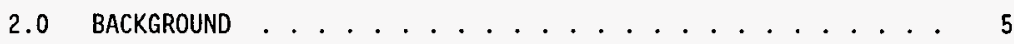

3.0 FUNCTIONAL REQUIREMENTS ................ . . 5

3.1 MINIMUM CONDITIONS DEFINING EQUIVALENT

ALTERNATE MONITORING . . . . . . . . . . 6

3.1.1 291-Z-1, 296-Z-3, and 296-Z-5 Stack CAMs . . . . . . . . . . . . . 6

$3.1 .2296-Z-6$ Stack CAMs . . . . . . . . . . 7

3.3 296-Z-14 Stack CAMs ........... 8

4.0 SAFETY ENVELOPE EQUIPMENT . . . . . . . . . . . . . 9

4.1 SAFETY ENVELOPE EQUIPMENT COMMON TO ALL STACKS . . . . 9

4.2 291-Z-1 SAFETY ENVELOPE EQUIPMENT . . . . . . . . 10

$4.3296-Z-3$ SAFETY ENVELOPE EQUIPMENT . . . . . . . . . . 11

$4.4296-Z-5$ SAFETY ENVELOPE EQUIPMENT . . . . . . . . 12

$4.5296-Z-6$ SAFETY ENVELOPE EQUIPMENT . . . . . . . . . . 13

$4.6296-Z-14$ SAFETY ENVELOPE EQUIPMENT $\ldots \ldots \ldots$

4.7 COMPONENTS EXCLUDED FROM THE SAFETY

ENVELOPE ................... 16

5.0. SAFETY ENVELOPE PROCEDURES ................ . . 18

5.1 SE ALARM RESPONSE PROCEDURES . . . . . . . . . 18

5.2 SE RADIOLOGICAL CONTROL PROCEDURES $\ldots \ldots \ldots$

6.0 SAFETY ENVELOPE SURVEILLANCE REQUIREMENTS . . . . . . . . . 19

7.0 REFERENCES ........................ 20

APPENDIX A - OSR LCO COMPLIANCE SHEET . . . . . . . . . . 21

APPENDIX B - MASTER COMPONENT INDEX INPUT LIST . . . . . . . . 25 


\section{LIST OF ACRONYMS}

ANSI

CAM

DOE

EP

FSAR

HEPA

HP

HPT

LCO

OSR

PFP

RAP

SAR

SE

SR

WHC

\section{STACK}

\section{1-Z-1}

296-Z-3

296-Z-5

296-Z-6

296-Z-14

\author{
American National Standards Institute \\ continuous air monitors \\ U. S. Department of Energy \\ Environmental Protection \\ final safety analysis report \\ high efficiency particulate air \\ Health Physics \\ Health Physics Technician \\ limiting condition for operation \\ Operational Safety Requirement \\ Plutonium Finishing Plant \\ regulating air pump \\ safety analysis report \\ safety envelope \\ Surveillance Requirement \\ Westinghouse Hanford Company
}

STACK \& BUILDING CROSS REFERENCE

\section{BUILDINGS EXHAUSTED}

234-5Z, 236-Z, 242-Z

241-Z Sumps and Tanks

2736-ZB

2736-Z (stack located at 2736-ZA)

$232-Z$ 
1.0

2.0

3.0

PURPOSE

This document provides a description of the Effluent Stack Monitors' portion of the Plutonium Finishing Plant (PFP) Safety Envelope (SE). Included is amplification in detail of the Limited Condition for Operation (LCO) described in the Plutonium Finishing Plant Operational Safety Requirements, WHC-SD-CP-OSR-010, Rev. 0, May 1995 Section 3.2.2, "Effluent Stack Air Monitors and Alarms." This additional detail clarifies the term "OPERABLE" and defines the components in the 291-Z-1, $296-Z-3,296-Z-5,296-Z-6$, and 296-Z-14 stack monitoring systems that comprise the system safety boundary and are essential to OSR compliance. This paper is intended to support the FSAR implementation by providing a system description and the necessary technical bases for the system.

This document, with its appendices, also provides the following:

1. A list of the safety envelope equipment (Appendix B)

2. Descriptions of the purpose and function of safety envelope equipment. (Section 4)

3. A list of the operational, al arm response, maintenance, and surveillance procedures necessary to operate and maintain the system equipment within the safety envelope. (Sections 5 and 6$)$

\section{BACKGROUND}

The Effluent Stack Air Monitors and Alarms provide continuous, verification of HEPA filter integrity and ensure prompt detection of elevated plutonium concentrations in effluent air. The

WHC-SD-CP-OSR-010 requirements for the Effluent Stack Monitors system are strongly influenced by the requirements of WHC-CM-7-5, Environmental Compliance Manual, 2.0 Air Quality, Radioactive Sources which

acknowledges specific time limitations for system maintenance. The accident analysis section (Chapter 9) of the PFP Final Safety Analysis Report (FSAR), WHC-SD-CP-SAR-021, Rev. 0, Jan. 1995, does not define an OPERABLE Effluent Stack Monitor system nor does it consider system downtime. Chapter 9 also does not base any accident scenario conclusions on probabilistic analys is of the Effluent Stack Monitors operability or reliability. Therefore, this document provides the definition of OPERABILITY as used in LCO 3.2.2 in terms of specific equipment, instrumentation and parameters, and it provides the technical basis for allowable system downtime for maintenance and other activities.

\section{FUNCTIONAL REQUIREMENTS}

Because the FSAR accident analysis does not define an OPERABLE Effluent Stack Monitor system, OPERABLE shall be defined to meet the intent of U.S. Department of Energy (DOE) Guide DOE/EH-0173T. The guide mandates that effluent monitor performance shall be sufficient to enable the DOE contractor to determine whether releases of airborne radioactive 
materials are within the limits specified in DOE Order 5400.5 .

Therefore, OPERABLE must be defined by a set of criteria consistent with the safety and regulatory functions of the monitors. The essential components described in Section 4.0. provide specific functions necessary to ensure performance of each monitor. These components must be fully functional for a stack monitor to be deemed OPERABLE.

During periods when a stack monitor is not OPERABLE, equivalent alternate monitoring must be provided to comply with DOE/EH-0173T, Chapter 3.0, Section 3.3. For these abnormal periods the minimum conditions which define equivalent alternate monitoring are described in Section 3.1.

\subsection{MINIMUM CONDITIONS DEFINING EQUIVALENT ALTERNATE MONITORING}

During abnormal operating conditions, such as an essential component failure or failure of a monthly surveillance, the minimum conditions described below define one method of equivalent acceptable alternative monitoring. The following definition does not preclude other alternative means of monitoring which may be employed in special situations, however other methods must obtain prior approval from Air and Water Services.

\subsubsection{1-Z-1, 296-Z-3, and 296-Z-5 Stack CAMs}

The CAMs at the 291-Z-1 (234-5Z, 236-Z and $242-Z$ buildings), $296-Z-3$ (241-Z sumps and tanks), and 296-Z-5 (2736-ZB building) stack monitors provide equivalent alternate monitoring if the following conditions are met:

1) The vacuum pump for the CAM is providing adequate motive force to sample the effluent stream at the prescribed sample rate $(2.0 \mathrm{cfm} \pm 20 \%)$ and a means of flow measurement is functional.

2) The CAM passes the inspection described in $2 \mathrm{H}-100-101$, PFP Shiftly Gaseous Effluent Sampling and Monitoring System Operability Inspection.

3) The CAM alarms annunciate locally and remotely.

$\underline{\mathrm{OR}}$

The operation of all components with failed or spurious remote alarms is verified every 2 hours.

4) If criteria 2 and 3 above cannot be met, then perform manual counting of the CAM or Record Sample filter media at 2 hour intervals.

Basis: DOE/EH-0173T, Chapter 3.0, Section 3.3, states the performance of airborne emissions monitoring systems shall be sufficient to enable the DOE contractor to determine whether the release of radioactive materials are within the limits specified in DOE Order 5400.5. 


\subsubsection{6-Z-6 Stack CAMs}

The 296-Z-6 (2736-ZA building) stack monitor CAMs (two, one for each filter bank) provide equivalent alternate monitoring if the following conditions are met. These conditions only apply to the CAM if its respective filter bank is active.

1) The $17^{\prime \prime}$ vacuum pump in $291-Z$ is providing adequate motive force to sample the effluent stream for the $\mathrm{CAM}(\mathrm{s})$ at the prescribed sample rate $(2.0 \mathrm{cfm} \pm 20 \%)$ and a means of flow measurement for the CAM is functional.

2) The CAM(s) pass the inspection described in ZH-100-101, PFP Shiftly Gaseous Effluent Sampling and Monitoring System Operability Inspection.

3) The CAM alarms annunciate locally and remotely.

\section{$\underline{\mathrm{OR}}$}

The operation of all components with failed remote alarms is verified every 2 hours.

4) If criteria 2 and 3 above cannot be met, then perform manual counting of the CAM or Record Sample filter media at 2 hour intervals.

5) If the criteria above cannot be met for the stack CAMs, then the facility may rely on the room CAMs if all of the room CAM's in $2736-Z$ satisfy criteria 1 through 3 above. Room 221-A RCT office Annunciator Pane 1 Windows \#25 and \#26 can be inspected, and the pane1 test button pushed, at least every 2 hours to satisfy the requirment for a continuously manned location.

Basis: DOE/EH-0173T, Chapter 3.0, Section 3.3, states the performance of airborne emissions monitoring systems shall be sufficient to enable the DOE contractor to determine whether the release of radioactive materials are within the limits specified in DOE Order 5400.5.

Basis: The alternative use of vault CAMs as backup indicators (criteria 5) for stack releases is justified because they provide early detection of the initial unmitigated release of radionuclides into the vault space due to a breach of the storage containers. The source term in the vault space is limited to sealed containers. Therefore, the CAMs located in the vault spaces provide the same function as the stack CAM, merely on the upstream side of the high efficiency particulate air (HEPA) filters. 


\subsubsection{6-Z-14 Stack CAMs}

The CAMs at the 296-Z-14 (232-Z building) stack monitor (two, redundant) provide equivalent alternate monitoring if the following conditions are met:

1) At least one vacuum pump is providing adequate motive force to sample the effluent stream at the prescribed sample rate $(2.0 \mathrm{cfm} \pm 20 \%)$ for at least one CAM and a means of flow measurement is functional.

2) At least one CAM passes the inspection described in ZH-100-101, PFP Shiftly Gaseous Effluent Sampling and Monitoring System Operability Inspection.

3) The CAM alarms annunciate locally and remotely.

$\underline{\mathrm{OR}}$

The operation of all components with failed or spurious remote alarms is verified every 2 hours.

4) If criteria 2 and 3 above cannot be met, then perform manual counting of the CAM or Record Sample filter media at 2 hour intervals.

Basis: DOE/EH-0173T, Chapter 3.0, Section 3.3, states the performance of airborne emissions monitoring systems shall be sufficient to enable the DOE contractor to determine whether the release of radioactive materials is within the limits specified in DOE Order 5400.5 .

Basis: The 296-Z-14 stack monitor is equipped with 2 CAMs which provide redundant service. Only one CAM is required to monitor the effluent stream in the event of a CAM failure.

\subsection{FUNCTIONAL DOWNTIME CRITERIA}

Many activities require some degree of freedom for testing, surveillance, operations activities, and maintenance. Brief periods of inoperability represent very low risk, yet yield great benefits in reliability and functionality. Reference WHC-CM-7-5 Section 2.5.3.2 for CAM downtime criteria. The PFP Stacks and their respective current WHC-CM-7-5 designations (defined in WHCEP-0894) are as follows: 291-Z-1 (Category A or I), 296-Z-3, -5, 6 , and -14 (Category $B$ or II). Downt ime for Category B/II stacks is not specifically defined in WHC-CM-7-5 and therefore will be managed in the same manner as PFP's Category A/I stack (291-Z-1) as a best management practice. 
The various stack monitors have many individual components. Although each component performs some role in the overall function of the Effluent Stack Monitoring system, not all are directly related to the system's safety function. The components critical to the safety function of each Stack monitor are included in the safety envelope. The safety envelope equipment common to all five stacks is identified in Section 4.1. The safety envelope equipment unique to each stack is identified in Sections 4.2 through 4.6. Equipment excluded from the safety envelope and the reasoning behind these exclusions is explained in Section 4.7 .

\subsection{SAFETY ENVELOPE EQUIPMENT COMMON TO ALL STACKS}

Several components in the stack effluent monitoring system safety envelope are common to all five of the stacks covered by LCO 3.2.2. Each of these components and their design functions are described below. Alarm annunciator panel window identification is referenced first by window label and second, in parentheses, by the vendor reference.

\section{- Room 714 Alarm Annunciator Panel}

Room 714 annunciator panel provides visual and audible stimuli to critical response personnel in the event of an effluent monitoring system alarm, loss of power, or loss of continuity in the alarm wiring. The panel is in the primary continuously manned location. The specific alarms indicated on the panel are summarized in Sections 4.2 through 4.6. Only the alarm windows servicing the effluent monitoring system are included in the safety envelope.

- Room 714 Annunciator Panel Horn

The annunciator horn provides audible stimuli to critical response personnel for any alarm relayed to the panel. The horn provides a redundant indication of an alarm.

\section{- Room 714 Annunciator Panel Reset/Silence Button}

The reset/silence button silences the annunciator horn. The button also resets the alarm, if depressed after the alarm has cleared. 


\subsection{1-Z-1 SAFETY ENYELOPE EQUIPMENT}

Components of the 291-Z-1 (234-5Z, 236-Z and 242-Z buildings) stack monitor included in the safety envelope are identified in this section. Each of these components and their design functions are described below.

- Sample collection Probe, Flow Splitter, and Piping

The sample collection probe, flow splitter, and piping that make up the sample collection and delivery system are constructed in accordance with American National Standards Institute (ANSI) N13.1, 1969. The probe collects a near-isokinetic sample for delivery through the piping and to the sample heads. The piping included in the safety envelope ends at the CAM Vacuum Switch. Exhaust piping is not included.

\section{- Continuous Air Monitor}

The CAM provides the primary alert of elevated radionuclide emissions. This allows facility management to respond in a timely fashion to mitigate the release. The CAM's detection efficiency must be at least 7 percent and all alarms (high radiation, low count, and failure) must be functional.

\section{- CAM Flow Rate Indicator}

The flow rate indicator is an integral part of the CAM and is used to verify that the flow rate through the CAM meets the requirements specified in Surveillance Requirements (SR) 3.2.2.1.

\section{- caM Vacuum Switch}

The vacuum switch provides an alarm signal to the annunciator panel in Room 714 of building 234-5Z if the vacuum supply fails. The switch will initiate an alarm due to either high vacuum or low vacuum conditions.

- Room 714 A1arm Annunciator Window No. 1 (1A)

This annunciator window provides visual stimuli to critical response personnel in the event of a CAM high radiation condition at stack 291-Z-1.

- Room 714 Alarm Annunciator Window No. 2 (2A)

This annunciator window provides visual stimuli to critical response personnel in the event of a CAM failure condition at stack $291-Z-1$. 
- Room 714 Alarm Annunciator Window No. 3 (3A)

This annunciator window provides visual stimuli to critical response personnel in the event of a vacuum supply failure condition relayed by the CAM vacuum switch at stack 291-Z-1.

\section{$4.3 \quad 296-2-3$ SAFETY ENVELOPE EQUIPMENT}

Components of the 296-Z-3 (241-Z sumps and tanks) stack monitor included in the safety envelope are identified in this section. Each component is listed and described, and its design function is explained.

\section{- Sample Collection Probe, Flow Splitter, and Piping}

The sample collection probe, flow splitter, and piping that make up the sample collection and delivery system is constructed in accordance with ANSI N13.1, 1969. This probe collects a near-isokinetic sample for delivery through the piping and to the sample heads. The piping included in the safety envelope ends at the CAM Vacuum Switch. Exhaust piping is not included.

- Continuous Air Monitor

The CAM provides the primary alert of elevated radionuclide emissions. This allows facility management to respond in a timely fashion to mitigate the release. The CAM's detection efficiency must be at least 7 percent and all alarms (high radiation, low count, and failure) must be functional.

\section{- CAM flow Rate Indicator}

The flow rate indicator is an integral part of the CAM and is used to verify that the flow rate through the CAM meets the requirements specified in SR 3.2.2.1.

\section{- Car Vacuum Switch}

The vacuum switch provides an alarm signal to the annunciator panel in Rooms 714 of building 234-5Z if the vacuum supply fails. The switch will initiate an alarm due to either high vacuum or low vacuum conditions.

- Room 714 Alarm Annunciator Window No. 6 (1B)

This annunciator window provides visual stimuli to critical response personnel in the event of a CAM high radiation condition at stack 296-Z-3. 
- Room 714 Alarm Annunciator Window No. 7 (2B)

This annunciator window provides visual stimuli to critical response personnel in the event of a CAM failure condition at stack 296-Z-3.

- Room 714 Alarm Annunciator Window No. 8 (3B)

This annunciator window provides visual stimuli to critical response personnel in the event of a vacuum supply faiture condition relayed by the vacuum switches at stack 296-Z-3. Both the CAM and record sampler vacuum switches are latched and relayed together; consequently, there is no indication of which sampling loop is troubled.

\subsection{6-Z-5 SAFETY ENVELOPE EQUIPMENT}

Components of the 296-Z-5 (2736-ZB building) stack monitor included in the safety envelope are identified in this section. Each of these components and their design functions are described below.

- CAM Sample Collection Probe and Piping

The CAM sample collection probe and piping that make up the sample collection and delivery system is constructed in accordance with ANSI N13.1, 1969. This probe collects a near-isokinetic sample for delivery through the piping and to the sample head. The piping included in the safety envelope ends at the CAM and includes the piping which connects Vacuum Switch VS-CAM-Z5 in Room 600 of 2736-ZB to the $17^{\prime \prime}$ vacuum header piping.

- Continuous Air Monitor

The CAM provides the primary alert of elevated radionuclide emissions. This allows facility management to respond in a timely fashion to mitigate the release. The CAM's detection efficiency must be at least 7 percent and all alarms (high radiation, low count, and failure) must be functional.

- CaM flow Rate Indicator

The flow rate indicator is an integral part of the CAM and is used to verify that the flow rate through the CAM meets the requirements specified in SR 3.2.2.1.

\section{- Building 2736-ZB Vacuum Switch}

This vacuum switch provides an alarm signal to the annunciator panel in building 234-5Z, Room 714. The switch will initiate an alarm due to a low vacuum condition. 
- Room 714 Alarm Annunciator Window No. 11 (6A)

This annunciator window provides visual stimuli to critical response personnel in the event of a CAM high radiation condition at stack 296-Z-5.

- Room 714 Alarm Annunciator Window No. 12 (7A)

This annunciator window provides visual stimuli to critical response personnel in the event of a CAM failure condition at stack $296-Z-5$.

- Room 714 Alarm Annunciator Window No. 13 (8A)

This annunciator window provides visual stimuli to critical response personnel in the event of a loss of vacuum condition in building 2736-ZB.

\subsection{6-Z-6 SAFETY ENVELOPE EQUIPMENT}

Components of the 296-Z-6 (2736-ZA building) stack monitor included in the safety envelope are identified in this section. Each of these components and their design functions are described below.

\section{- East and West Filter Bank CAM Sample Collection Probes}

The CAM sample collection probes and piping that make up the sample collection and delivery system are constructed in accordance with ANSI N13.1, 1969. The probes collect near-isokinetic samples for delivery through the piping to the sample heads. The piping included in the safety envelope ends at the CAM and includes the piping which connects Vacuum Switch PS-5900-23A to the 17" vacuum header piping.

- East and West Filter Bank Alpha CAMs

The CAMs provide the primary alert of elevated radionuclide emissions. This allows facility management to respond in a timely fashion to mitigate the release. Each CAM's detection efficiency must be at least 7 percent and all a larms (high radiation, low count, and failure) must be functional.

\section{- East and West Filter Bank Alpha CAM Sample Flow Indicators}

The flow rate indicators are an integral part of each CAM and are used to verify that the flow rate through the CAMs meets the requirements specified in SR 3.2.2.1. 
- East and Hest Filter Bank Alpha CAM Sample Flow Control Valve

The valve on the outlet side of each CAM provides primary sample flow rate control.

- Building 2736-ZA Vacuum Switch

This vacuum switch provides an alarm signal to the annunciator panel in Rooms 714 of building 234-5Z if the vacuum supply fails. The switch will initiate an alarm due to a low vacuum condition.

- Room 714 Alarm Annunciator Window No. 16 (6B)

This annunciator window provides visual stimuli to critical response personnel in the event of an east filter bank CAM high radiation condition at stack 296-Z-6.

- Room 714 Alarm Annunciator Window No. 17 (7B)

This annunciator window provides visual stimuli to critical response personnel in the event of a east filter bank CAM failure condition at stack 296-Z-6.

- Room 714 Alarm Annunciator Window No. 18 (8B)

This annunciator window provides visual stimuli to critical response personnel in the event of a loss of instrument vacuum condition in building $2736-Z$.

- Room 714 Al arm Annunciator Window No. 21 (11A)

This annunciator window provides visual stimuli to critical response personnel in the event of an west filter bank CAM high radiation condition at stack 296-Z-6.

- Room 714 Alarm Annunciator Window No. 22 (12A)

This annunciator window provides visual stimuli to critical response personnel in the event of an west filter bank CAM failure condition at $296-\mathrm{Z}-6$.

\subsection{6-Z-14 SAFETY ENVELOPE EQUIPMENT}

Components of the 296-Z-14 (232-Z building) stack monitor included in the safety envelope are identified in this section. Each component is listed and described, and its design function is explained. 
- CaM Sample Collection Probe, Flow Splitter, and Piping

The CAM collection probe, flow splitter, and piping that make up the sample collection and delivery system is constructed in accordance with ANSI N13.1, 1969. This probe collects a near-isokinetic sample for delivery through the piping to the sample heads. The piping included in the safety envelope ends at the outlet side of the vacuum pumps. Exhaust piping is not included.

- Upper and Lower Alpha CAMs

The CAMs provide the primary alert of elevated radionuclide emissions. This allows facility management to respond in a timely fashion to mitigate the release. Each CAM's detection efficiency must be at least 7 percent and all alarms (high radiation, low count, and failure) must be functional.

- Upper and Lower Alpha CAM Sample Flow Indicators

The flow rate indicators are an integral part of each CAM and are used to verify that the flow rate through the CAMs meets the requirements specified in SR 3.2.2.1.

- Upper and Lower Alpha CAM Sample Flow Switches

The flow switches provide an alarm signal to the local annunciator panel, which relays the signal to the panel in Room 714, 234-5Z. Each switch monitors the flow rate to the associated CAM and will initiate an alarm on a low flow condition.

- Room 714 Alarm Annunciator Window No. 25 (15A)

This annunciator window provides visual stimuli to critical response personnel in the event of a CAM high radiation condition, CAM failure condition or a CAM or record sampler low flow condition at the 296-Z-14 stack.

\section{- 296-Z-14 Local Alarm Annunciator Panel}

This annunciator panel provides visual indication to critical response personnel of specific stack monitor and sampler system alarms including CAM related alarms. A11 alarms from this panel are latched and relayed together to the Room 714 alarm panel. Consequently, there is no indication at the remote alarm panel in Room 714 of the exact cause of the alarm. Only the alarm windows and components identified below are included in the safety envelope. 
- 296-2-14 Local Alarm Annunciator Window Reset/Silence Button

The reset/silence button silences the annunciator horn. The button also resets the alarm, if depressed after the alarm has cleared.

- 296-2-14 Local Alarm Annunciator Window No. DS2

This annunciator window provides visual indication to critical response personnel in the event of an upper CAM low flow rate condition.

- 296-Z-14 Local Alarm Annunciator Window No. DS3

This annunciator window provides visual indication to critical response personnel in the event of a lower CAM low flow rate condition.

- 296-Z-14 Local Alarm Annunciator Window No. DS4

This annunciator window provides visual indication to critical response personnel in the event of an upper CAM high radiation condition.

- 296-Z-14 Local A1 arm Annunciator Window No. DS5

This annunciator window provides visual indication to critical response personnel in the event of an upper CAM failure condition.

- 296-Z-14 Local Alarm Annunciator Window No. DS6

This annunciator window provides visual indication to critical response personnel in the event of a lower CAM high radiation condition.

- 296-Z-14 Local A1 arm Annunciator Window No. DS7

This annunciator window provides visual indication to critical response personnel in the event of a lower CAM failure condition.

\subsection{COMPONENTS EXCLUDED FROM THE SAFETY ENVELOPE}

Selected components supporting the Stack Effluent Monitoring system are excluded from the safety envelope. These components are excluded because their function is not essential to the safety envelope function of the stack effluent monitoring system. A more complete description of these excluded components is provided below. 


\section{- Alarm Signal Wiring to Annunciator Panel Room 714}

All wiring associated with the alarm signal loops is excluded from the safety envelope. The system is designed to alarm on a loss of continuity in the alarm wiring. An alarm would allow operations to establish an alternate means of surveillance while the problem was being corrected.

\section{- Electrical Distribution System}

All PFP Effluent Stack Monitoring systems are supplied with power equivalent to that of their associated air movers. If normal power to the plant is interrupted (loss of offsite power), the 2721-Z diesel generators start automaticaliy to energize the back-up power distribution system, which includes the Stack Monitoring systems. Under these conditions the Stack CAM will provide monitoring capability as designed when ventilation is restarted. Therefore, Stack Effluent Monitoring is not interrupted.

If the diesel generators fail to start following a loss of offsite power (total loss of power), the monitor will be disabled while the steam-driven exhaust fans are operating. This event would initiate alarm response actions in accordance with defined procedures to place the facility in a safe shutdown mode and establish continuous monitoring capability.

Finally, if the power is lost to a specific CAM or vacuum pump, the instrument failure alarm or the loss of vacuum alarm will alert operations and management personnel of the condition. They can then take the necessary actions to return the power or vacuum to the system or provide an alternate means of monitoring the affected stack effluent.

\section{- Building Vacuum Systems and Local Vacuum Pumps}

Proper operation of the CAMs requires a vacuum source capable of withdrawing $2.0 \mathrm{cfm}$ from the stack. Three of the Stack Effluent Monitoring CAMs include portable oilless vacuum pumps, referred to as RAPs. Two of the systems, $296-Z-5$ and $296-Z-6$, use the $2736-Z B$ and $291-Z$ building vacuum systems, respectively, to withdraw the sample. These RAP and building vacuum systems have been excluded from the safety envelope because each system is equipped with a vacuum failure alarm which, in the event of a failure, would notify plant operators to initiate recovery actions. These alarms allow operators to establish alternate means of stack effluent monitoring in a timely manner. The CAM pressure/ flow switches which initiate the alarms and the associated alarm circuitry are included in the safety envelope. The functional tests and calibration procedures for these alarms are also required to maintain the safety envelope. 
5.0 .

\section{SAFETY ENVELOPE PROCEDURES}

The following procedures are required to ensure the intent of LCO 3.2.2 is satisfied whenever ventilation is being used to exhaust the buildings. The procedures include al arm response procedures and Health Physics procedures. Each procedure included in the safety envelope and the justification for its inclusion is presented below.

\subsection{SE ALARM RESPONSE PROCEDURES}

ZAR-001

This procedure provides response instruction for Operations personnel in the event of a Room 714 Annunciator Panel alarm. Response to stack related alarms under this procedure is limited mainly to RCT notification of the alarm condition. The RCT organization then responds per applicable $\mathrm{ZH}$ procedure.

\subsection{SE RADIOLOGICAL CONTROL PROCEDURES}

ZH-100-101, PFP Shiftly Gaseous Effluent Sampling and Monitoring System Operability Inspection.

This procedure provides RCT personnel with instruction necessary to perform shift-wise Operability inspections of all PFP Stack Monitors.

ZH-100-102, PFP Bi-Weekly Gaseous Effluent Sampling and Monitoring System Inspection and Sample Exchange.

This procedure provides RCT personnel with instruction necessary to perform routine bi-weekly sample collection and sampler Operability inspection for all PFP Stack Monitors.

ZH-100-107: RCT Response to Room 714 Annunciator Panel Stack CAM High Radiation Alarms.

This procedure provides Stack CAM High Radiation alarm response instruction for the RCT personnel. Response occurs upon notification of the alarm condition from Operations personnel in Rooms 714 (234-5Z). Room 714 is manned 24hours a day.

ZH-100-108: RCT Response to Room 714 Annunciator Panel Stack CAM Fai1, Low Flow, Loss of Vacuum Alarms.

This procedure provides all other stack related (e.g. CAM Fail, Low Flow) alarm response instructions for the RCT personnel. Response occurs upon notification of the alarm condition from Operations pesonnel in Rooms 714 (234-5Z). Room 714 is manned 24-hours a day. 
6.0

\section{SAFETY ENVELOPE SURVEILLANCE REQUIREMENTS}

The OSR requires surveillance activities to verify Stack Monitor operations. These include daily operation surveillances, functional testing, and calibrations. The procedures are described below.

The following procedure verifies the sample flow rate to the gaseous effluent monitors and the CAM alarm setpoint. This procedure satisfies Surveillance Requirements SR 3.2.2.1 and SR 3.2.2.2.

- $\quad$ ZH-100-101, PFP Shift-Wise Gaseous Effluent Sampling and Monitoring System and Operability Inspection.

The following five procedures functionally test the gaseous effluent monitor systems servicing the stacks specified in the procedure titles.

- ZSE-24A-001, Monthly 291-Z-1 Stack Effluent Monitor Functional Test.

- $\quad$ ZSE-24A-003, Monthly 296-Z-3 Stack Effluent Monitor Functional Test.

- ZSE-24A-005, Monthly 296-Z-5 Stack Effluent Monitor Functional Test.

- ZSE-24A-007, Monthly 296-Z-6 Stack Effluent Monitor Functional Test.

- $\quad$ 2SE-24A-009, Monthly 296-Z-14 Stack Effluent Monitor Functional Test.

These procedures satisfy Surveillance Requirement SR 3.2.2.3. They may also be used after corrective maintenance activities and may be performed in part or in their entirety.

The following five procedures calibrate the gaseous effluent monitors system components servicing the stacks specified in the procedure titles. These procedures satisfy Surveillance Requirement SR 3.2.2.4 for annual calibration. These procedures can also be used after corrective maintenance activities and may be performed in part or in their entirety.

- ZSE-24A-002, Annual 291-Z-1 Stack Effluent Monitor Calibration.

- ZSE-24A-004, Annual 296-Z-3 Stack Effluent Monitor Calibration.

- ZSE-24A-006, Annual 296-Z-5 Stack Effluent Monitor Calibration.

- ZSE-24A-008, Annual 296-Z-6 Stack Effluent Monitor Calibration.

- ZSE-24A-010, Annual 296-Z-14 Stack Effluent Monitor Calibration. 
40 CFR 61, "National Emission Standards for Hazardous Air Pollutants (NESHAPs), Subpart H."

ANSI N13.1, "Guide to Sampling Airborne Radioactive Materials in Nuclear Facilities, 1969."

DOE 5400.1, "General Environmental Protection Program."

DOE 5400.5, "Radiation Protection of the Public and the Environment."

DOE 5484.1, "Environmental Protection, Safety, and Health Protection Information Reporting Requirements."

DOE/EH-0173T, "Environmental Regulatory Guide for Radiological Effluent Monitoring and Environmental Surveillance", January 1991.

DOE/EP-0096, "A Guide for Effluent Radiological Measurements at DOE Installations", July 1983.

$\mathrm{DOE} / \mathrm{EV} / 1830-\mathrm{T5}$, "A Guide to Reducing Radiation Exposure to as Low as Reasonably Achievable", Apri1 1980.

General Regulation 80-7, "Benton-Franklin-Walla Walla Counties Air Pollution Control Authority (APCA)", July 1980.

WAC 173-400, "General Regulations for Air Pollution Sources."

WAC 246-247, "Radiation Protection."

WHC-CM-4-1, "Health Physics Procedures."

WHC-CM-7-5, "Environmental Compliance."

Section 2.0, "Air Quality."

Section 5.0, "Records, Reporting and Response Activities." Appendix A, "Glossary."

Appendix C, "Derived Concentration Guides."

WHC-IP-0718, Rev. 0 "Health Physics Procedures."

WHC-SD-CP-SAR-021, Rev. 0, "Plutonium Finishing Plant Final Safety Analysis Report." WHC-SD-CP-OSR-010, Rev. 0, "Plutonium Finishing PTant Operational Safety Requirements." 


\section{APPENDIX A - OSR LCO COMPLIANCE SHEET}

\section{OSR LCO CONPL WNCE SHEET}

APPLICABLE OSR LCO (WHC-SD-CP-0SR-010, Rev, 0, section 3.0):

\subsubsection{Effluent Stack Air Wonitors and Alarms}

LCO 3.2.2 The alpha continuous air monitors (CAMs) for the 291-z-1, 296-z-3, 296-z-14, 296-z-5, and 296-z-6 stacks shall be OPERABLE.

APPLICABILITY: ALL MODES if forced exhaust ventilation is occurring ACTIONS:

\begin{tabular}{|c|c|c|c|}
\hline & CONDITION & REQUIRED ACTION & $\begin{array}{c}\text { COMPLETION } \\
\text { TIME }\end{array}$ \\
\hline & A stack alpha CAM is inoperable. & $\begin{array}{l}\text { A.1 } \\
\text { Establ ish equivalent al ternate } \\
\text { monitoring. } \\
\text { AND } \\
\text { A.2.1 } \\
\text { Restore stack alphe CAM to an } \\
\text { OPERABLE condition. } \\
\text { OR } \\
\text { A.2.2.1 } \\
\text { Enter MODE 2, Limited Plutonium } \\
\text { Handling Operations in the } \\
\text { affected process area(s). } \\
\text { Discont inue plutoniun processing } \\
\text { and handl ing in affected process } \\
\text { area(s). } \\
\text { AND } \\
\text { A.2.2.2 } \\
\text { Initiate a written RECOVERY PLAN } \\
\text { to restore the Stack alphe CAM } \\
\text { to an OPERABLE condition. }\end{array}$ & $\begin{array}{l}2 \text { Hours } \\
72 \text { Hours } \\
72 \text { Hours }\end{array}$ \\
\hline
\end{tabular}




\section{OSR LCO COHPL TANCE SHEET}

APPLICABLE 0SR LCO (UHC-SD-CP-0SR-010, ReV, 0, Section 3.0):

\subsubsection{Ef fluent Stack Air Monitors and Alarms}

\section{SURVEILLANCE REQUIRENENTS:}

\begin{tabular}{|c|c|c|}
\hline & SURVEILLANCE & FREQUENCY \\
\hline SR 3.2 .2 .1 & VERIFY each stack alpha CAM sample flow rate is $2.0 \mathrm{cfm} \pm 20 \%(1.6-2.4 \mathrm{cfm})$. & Daily \\
\hline SR 3.2.2.2 & $\begin{array}{l}\text { VERIFY each stack alpha CAM alarm setpoint is less than the equivalent of } 20,000 \\
\text { DCG-h. }\end{array}$ & Daily \\
\hline SR 3.2 .2 .3 & $\begin{array}{l}\text { Perform FUNCTIONAL TEST of each stack alpha monitoring instrument and it's } \\
\text { associated failure and high concentration alarm. }\end{array}$ & Monthly \\
\hline SR 3.2 .2 .4 & CALIBRATE each stack alpha monitoring instrument. & Annually \\
\hline \multicolumn{3}{|l|}{ APPLICABLE } \\
\hline $\begin{array}{l}9.1 .1 \\
9.1 .2 \\
9.1 .3 \\
9.1 .4 \\
9.1 .5\end{array}$ & $\begin{array}{l}\text { Radioisotope-Bearing Liquid Spills } \\
\text { Radioisotope-Bearing Pressurized Liquid Container } \\
\text { Radioisotope-Bearing Powder Spills } \\
\text { Radioisotope-Bearing Pressurized Powder Container } \\
\text { Stack Release Resulting From Filter Changes }\end{array}$ & \\
\hline $\begin{array}{l}9.1 .7 \\
9.1 .8 \\
9.1 .9 \\
9.2 .2\end{array}$ & $\begin{array}{l}\text { Ventilation System Upsets } \\
\text { Loss of Vent ilation } \\
\text { Glovebox Glove Breach } \\
\text { Fire }\end{array}$ & \\
\hline
\end{tabular}

\section{APPLICABLE PLANT/PROCESS DESIGN/OPERATION DESCRIPTION(S) [FSAR CHAPTER/ SECTION]:}

4.3.5.3 Radiation Alarm Systems

5.4.10.1.6 Stack Monitors

5.4.10.2.1 Emergency Signals and Responses

7.1.1.3.2 Continuous Monitoring and Alarms

7.2.1 Radioactive Gaseous Effluents

8.6.1.1.2 Monitoring Capabilities

\section{SYSTEM DRAWINGS [H-2- XXXXXX, sheet $\mathrm{XX}$ ]}

$\mathrm{H}-2-28364$. Functional Diagram Stack Sampler \& Drawing Index

H-2-96431 CAM Alarm Annunciator Panel Relocstion

H-2-815175, Functional Diagram Stack Samplers

H-2-96401, Annuncistor ANN-714

\section{TWPLEMENT ING PROCEDURES/ COHPL TANCE VERIFICAT ON}

\section{OPERATING [Z0-series]:}

20-060-117, Perform Power Equipment Surveillance

20-060-612; Operate Air Sampler Vacuum

20-060-622, Operate 291-Z Air Sampler Vacuum Pumps with closed Loop Cooling

ZAR-001, ANN-714 Panel Alarms 


\section{OSR LCO CONPLIANCE SHEET}

APPLICABLE OSR LCO (WHC-SO-CP-OSR-010, ReV, 0, Section 3.0):

\subsubsection{Effluent stack AIr Monjtors and Alarms}

LABORATORY [LO-, LA- series]: NONE

\section{HEALTH PHYSICS:}

PFP Facility Specific Radiological Control Procedures (ZHs)

2H-100-101. Perform Shiftly Gaseous Effluent Sampling and Monitoring System Dperability Inspection

ZH-100-102, Perform Bi-Weekly Gaseous Effluent Sempl ing and Monitoring System Inspection and Sanple Exchange

ZH-100-107, RCT Response to Room 714 Annunciator Panel stack CAM High Radiation Alarms

ZH-100-108, RCT Response to Room 714 Annunciator Panel stack CAM Fail, Low Flow, Loss of Vacuum Alarms

\section{SUPPORTING DOCUMENTS:}

WHC-SD-CP-SDO-006, Definition and Means of Maintaining the Effluent Stack Monitors Portion of the PFP Safety Envelope 


\begin{tabular}{|c|c|c|c|}
\hline \multicolumn{4}{|c|}{$\begin{array}{r}\text { OSR LCO COMPL IANCE SHEET } \\
\end{array}$} \\
\hline \multicolumn{4}{|c|}{$\begin{array}{r}\text { APPLICABLE OSR LCO (WHC-SD-CP-OSR-010, ReV, 0, SeCtion 3.0), } \\
3.2 .2 \text { Effluent Stack AIr Monitors and ATarms }\end{array}$} \\
\hline \multicolumn{4}{|c|}{$\begin{array}{l}\text { ADMINISTRATIVE [WHC-5-8, etc]: } \\
\text { WHC-CM-5-8, Plutonium Finishing Plant Administration Manual } \\
\text { 1.5, Non-Rout ine Release Response } \\
\text { 1.31, Operat ion of Radioactive Airborne Effluent Monitors }\end{array}$} \\
\hline \multicolumn{4}{|c|}{$\begin{array}{l}\text { MAINTENANCE [2Z-, 1-ZM-, etc]: NON-LCO } \\
\text { PSCP-4-007, Rockwell Type Gas Meter } \\
\text { 1-2M-094, Stack Effluent Systems, Vacuum Pump Replacement and Terporary Instal lation } \\
2218379 \text {, CAM Chart Change }\end{array}$} \\
\hline $\begin{array}{l}\text { SURVEILLANCE } \\
\text { REQUIREMENT }\end{array}$ & PROCEDURE NUMBER & DESCRIPTION & $\begin{array}{l}\text { PROCEDURE } \\
\text { FREQUENCY }\end{array}$ \\
\hline SR 3.2.2.1 and SR 3.2.2.2 & $\begin{array}{l}2 H-100-101 \\
\text { (All stacks) }\end{array}$ & $\begin{array}{l}\text { Operability Check } \\
\text { (RCT Procedure) }\end{array}$ & $\begin{array}{l}\text { Shiftly } \\
\text { (minimum of } \\
\text { Daily) }\end{array}$ \\
\hline \multirow[t]{5}{*}{ SR 3.2 .2 .3} & ZSE-24A-001 (291-Z-1) & Functional Test \& CAM Exchange & Monthly ${ }^{\star}$ \\
\hline & ZSE-24A-003 (296-2-3) & Functional Test \& CAM Exchange & Monthly \\
\hline & $2 S E-24 A+005(296-2-5)$ & Functional Test \& CAM Exchange & Monthly ${ }^{*}$ \\
\hline & ZSE-24A-007 (296-Z-6) & Functional Test \& CAM Exchange & Monthly ${ }^{*}$ \\
\hline & $2 S E-24 A-009(296-Z-14)$ & Functional Test \& CAM Exchange & Monthly ${ }^{*}$ \\
\hline \multirow[t]{5}{*}{ SR 3.2 .2 .4} & $2 S E-24 A-002(291-Z-1)$ & Calibration & Annual * \\
\hline & $2 S E-24 A-004(296-2-3)$ & Calibration & Annual ${ }^{*}$ \\
\hline & ZSE-24A-006 (296-2-5) & Calibration & Annual ${ }^{*}$ \\
\hline & ZSE-24A-008 (296-Z-6) & Calibration. & Annual ${ }^{*}$ \\
\hline & ZSE-24A-010 (296-Z-14) & Calibration & Annual ${ }^{*}$ \\
\hline \multicolumn{4}{|c|}{ * and as needed for corrective maintenance } \\
\hline \multicolumn{4}{|l|}{ OTHER: NONE } \\
\hline
\end{tabular}




\begin{tabular}{|c|c|c|}
\hline \multicolumn{3}{|c|}{ OSR SYSTEAS COMPUTHCE SHEET } \\
\hline \multicolumn{3}{|c|}{ APPLICABLE OSR LCO (HHC-SD-CP-0SR-010 Section 3,0$)$. } \\
\hline \multicolumn{3}{|c|}{ is and Alarms } \\
\hline \multicolumn{3}{|c|}{ SAFETY ENYELOPE EQUTPHENT/CONPONENT LIST } \\
\hline $\begin{array}{l}\text { WASTER } \\
\text { COMPONETT LNDX } \\
\text { NUMBER }\end{array}$ & $\begin{array}{l}\text { FUNCTIONAL } \\
\text { DESCRIPTTION }\end{array}$ & DRAWING NUNBER \\
\hline \multicolumn{3}{|c|}{ COMHON EQUIPNENT } \\
\hline ANN -714 & Room 714 Al arm Annunciator Panel & H-2-96401, Sheet 2 \\
\hline ANN-714-HORN & Room 714 Al arm Panel Annunciator Horn & H-2-96401, Sheet 2 \\
\hline ANN-714-RESET & $\begin{array}{l}\text { Room } 714 \text { Alarm Panel Annunciator } \\
\text { Reset/Silence Button }\end{array}$ & H-2-96401, sheet 2 \\
\hline \multicolumn{3}{|c|}{$291-2-1$ STACK } \\
\hline PROBE-SPL-Z1 & Sample Collection Probe & $\mathrm{H}-2-28358$ \\
\hline SPLIT-CAM-Z1 & Sample Flow Splitter & $H-2-28360$ \\
\hline CAM-21 & Alpha CAM & $\mathrm{H}-2-28364$ \\
\hline$F I-C A M-21$ & Alpha CAM Flow Indicator & $H-2-28364$ \\
\hline VS-CAM-Z1 & CAM Vacurm switch & $\mathrm{H}-2-28364$ \\
\hline ANN-714-W1 & Rm.714 CAM High Rad. Alarm Window & $\mathrm{H}-2-96401$, Sheet 2 \\
\hline ANN-714-W2 & Rm.714 CAM Failure Alarm Window & H-2-96401, Sheet 2 \\
\hline ANN-714-W3 & Rm.714 CAM LOW Flow Window & H-2-96401, Sheet 2 \\
\hline \multicolumn{3}{|c|}{$296-Z-3$ STACK } \\
\hline PROBE-SPL-23 & Sample Collection Probe & $H-2-28358$ \\
\hline SPLIT-CAM-Z3 & Sample flow Splitter & $\mathrm{H}-2-28360$ \\
\hline CAM-23 & Alpha CAM & H-2-28365 \\
\hline FI-CAM-Z3 & Alpha CAM Flow Indicator & $\mathrm{H}-2-28364$ \\
\hline VS-CAM- 23 & CAM Vacuum Switch & $H-2-28364$ \\
\hline ANN-714-W6 & Rm.714 CAM High Rad. Alarm Window & H-2-96401, Sheet 2 \\
\hline ANN-714-W7 & Rm.714 CAM Failure Alarm Window & H-2-96401, Sheet 2 \\
\hline ANN-714-WB & $\begin{array}{l}\text { Rm. } 714 \text { CAM / Record Low Flow Atarm } \\
\text { Window }\end{array}$ & H-2-96401, Sheet 2 \\
\hline \multicolumn{3}{|c|}{ 296-Z-5 STACK } \\
\hline PROBE-CAM-25 & CAM Sample Collection Probe & H-2-815175, Sheet 3 \\
\hline CAM- 25 & Alpha CAM & H-2-815175, Sheet 3 \\
\hline FI-CAM- 25 & Alpha CAM Flow Indicator & H-2-815175, Sheet 3 \\
\hline VS-CAM-25 & Building 2736-2B Vacuum switch & H-2-815175, Sheet 3 \\
\hline
\end{tabular}




\begin{tabular}{|c|c|c|}
\hline \multicolumn{3}{|c|}{ OSR SYSTEMS COMPL IAUCE SHEET } \\
\hline \multicolumn{3}{|c|}{ 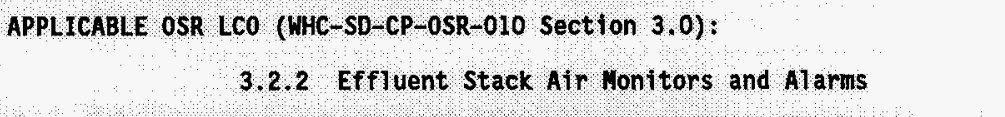 } \\
\hline \multicolumn{3}{|c|}{ 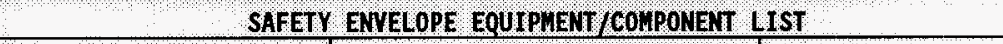 } \\
\hline $\begin{array}{l}\text { MASTER } \\
\text { CONPONETI INDEX } \\
\text { NUWBER }\end{array}$ & $\begin{array}{l}\text { EUNCTIONAL } \\
\text { DESCRIPIION }\end{array}$ & ORAWING NUMBER \\
\hline ANN-714-W11 & Rm.714 CAM High Rad. Alarm Window & $\mathrm{H}-2-96401$, sheet 2 \\
\hline ANN-714-W12 & Rm.714 CAM Failure Alarm Window & $\mathrm{H}-2-96401$, Sheet 2 \\
\hline ANN-714-W13 & $\begin{array}{l}\text { Rm. } 714 \text { Loss of Vacuum } 2736-2 B \text { Alarm } \\
\text { Window }\end{array}$ & H-2-96401, Sheet 2 \\
\hline \multicolumn{3}{|c|}{$296-2-6$ STACK } \\
\hline PROBE-CAM-Z6E & $\begin{array}{l}\text { East Filter Bank CAM Sample Collection } \\
\text { Probe }\end{array}$ & H-2-815175, Sheet 2 \\
\hline PROBE-CAM-Z6W & $\begin{array}{l}\text { West Filter Bank CAM Sample Collection } \\
\text { Probe }\end{array}$ & H-2-815175, Sheet 2 \\
\hline CAM-26E & East Filter Bank Alpha CAM & H-2-815175, Sheet ? \\
\hline CAM-26W & West Filter Bank Alpha CAM & $\mathrm{H}-2-815175$, Sheet 2 \\
\hline FI-CAM-Z6E & $\begin{array}{l}\text { East filter Bank Alpha CAM Sample Flow } \\
\text { Indicator }\end{array}$ & H-2-815175, Sheet 2 \\
\hline FI-CAM-26W & $\begin{array}{l}\text { West Filter Bank Alpha CAM Sample Flow } \\
\text { Indicator }\end{array}$ & H-2-815175, Sheet 2 \\
\hline PS - $5900-23 \mathrm{~A}$ & Building 2736-2A Vacuum Switch & $\mathrm{H}-2-140537$, Sheet 12 \\
\hline ANN-714-W16 & $\begin{array}{l}\text { Rm.714 East Filter Bank CAM High Rad. } \\
\text { Alarm Window }\end{array}$ & H-2-96401, Sheet 2 \\
\hline ANN-714-W17 & $\begin{array}{l}\text { Rm. } 714 \text { East Filter Bank CAM Failure } \\
\text { Alarm Window }\end{array}$ & H-2-96401, Sheet 2 \\
\hline ANN-714-W18 & $\begin{array}{l}\text { Rm. } 714 \text { Loss of Vacuum 2736-ZA Alarm } \\
\text { Window }\end{array}$ & H-2-96401, Sheet 2 \\
\hline ANN-714-W21 & $\begin{array}{l}\text { Rm. } 714 \text { West Filter Bank CAM High Rad. } \\
\text { Alarm Window }\end{array}$ & H-2-96401, Sheet 2 \\
\hline ANN-714-W22 & $\begin{array}{l}\text { Rm. } 714 \text { West Filter Bank CAM Failure } \\
\text { Alarm Window }\end{array}$ & $\mathrm{H}-2-96401$, Sheet 2 \\
\hline \multicolumn{3}{|c|}{$296-Z-14$ STACK } \\
\hline PROBE-CAM- Z14 & CAM Sample collection Probe & H-2-815175, Sheet 1 \\
\hline SPLIT - CAM-Z14 & CAM Sample flow Splitter & H-2-815175, Sheet 1 \\
\hline CAM-UPPER - Z14 & Upper Alpha CAM & $\mathrm{H}-2-815175$, Sheet 1 \\
\hline FI-UPPER - 214 & Upper Aloha CAM Sample Flow Indicator & H-2-815175, Sheet 1 \\
\hline FS-UPPER - Z14 & Upper Alpha CAM Sample FloH Switch & $\mathrm{H}-2-815175$, Sheet 1 \\
\hline CAM-LONER-Z14 & Lower Alpha CAM & $\mathrm{H}-2-815175$, Sheet 1 \\
\hline
\end{tabular}




\begin{tabular}{|c|c|c|}
\hline \multicolumn{3}{|c|}{ OSR SYSTEMS CONPLIANCE SHEET } \\
\hline \multicolumn{3}{|c|}{$\begin{array}{l}\text { APPLICABLE OSR LCO (WHC-SD-CP-OSR-010 Section 3,0), } \\
\qquad 3.2, \text { Effluent Stack Air Nonitors and Alarms }\end{array}$} \\
\hline \multicolumn{3}{|c|}{ SAFETY ENVELOPE EQUTPHENT/COHPONENT LIST } \\
\hline $\begin{array}{l}\text { MASTER } \\
\text { COMPONENT INDEX } \\
\text { NUHBER }\end{array}$ & $\begin{array}{l}\text { FUNCT IONAL } \\
\text { DESCRIPTION }\end{array}$ & DRAWING NUWBER \\
\hline FI-LOWER - Z14 & Lower Alpha CAM Sample Flow Indicator & H-2-815175, Sheet 1 \\
\hline FS-LOWER-Z14 & Lower Alpha caM Sample Flow switch & $\mathrm{H}-2-815175$, Sheet 1 \\
\hline PNL-214 & Local Alarm Annunciator Panel & $\begin{array}{l}\text { H-2-82838, Sheet } 1 \\
\text { H-2-815175, Sheet } 1\end{array}$ \\
\hline ANN-PNL-Z14_D\$2 & Low Flow CAM \#1 (Upper CAM) Alarm & $\begin{array}{l}\text { H-2- }-82838, \text { Sheet } 1 \\
\text { H-2-815175, Sheet } 1\end{array}$ \\
\hline ANN-PNL-214_DS3 & Low Flow CAM \#2 (Lower CAM) Alarm & $\begin{array}{l}\text { H-2-82838, Sheet } 1 \\
H-2-815175, \text { Sheet } 1\end{array}$ \\
\hline ANN-PNL-Z14_DS4 & High Rad. CAM \#1 (Upper CAM) Alarm & $\begin{array}{l}\text { H-2-82838, Sheet } 1 \\
\text { H-2-815175, Sheet } 1\end{array}$ \\
\hline ANN-PNL-Z14_DS5 & Fail caM \#1 (Upper CAM) Alarm & $\begin{array}{l}\text { H-2-82838, Sheet } 1 \\
\text { H-2-815175, Sheet } 1\end{array}$ \\
\hline$A N N-P N L-214 \_D S 6$ & High Rad. CAM \#2 (Lower CAM) Alarm & $\begin{array}{l}\text { H-2-82838, Sheet } 1 \\
\text { H-2-815175, Sheet } 1\end{array}$ \\
\hline ANN-PNL-214_DS7 & Fail CAM \#2 (Lower CAM) Alarm & $\begin{array}{l}\text { H-2-82838, Sheet } 1 \\
\text { H-2-815175, } \text { Sheet } 1\end{array}$ \\
\hline RESET-PNL-Z14 & $\begin{array}{l}\text { Local Alarm Annunciator Panel } \\
\text { Reset/Silence Button }\end{array}$ & $\begin{array}{l}\text { H-2-82838, Sheet } 1 \\
\text { H-2-815175, Sheet } 1\end{array}$ \\
\hline ANN-714-H25 & Rm.714 General Irouble Alarm Window & $\begin{array}{l}\text { H-2-96401, Sheet } 2 \\
\text { H-2-815175, Sheet 1 }\end{array}$ \\
\hline
\end{tabular}




\section{DISTRIBUTION SHEET}

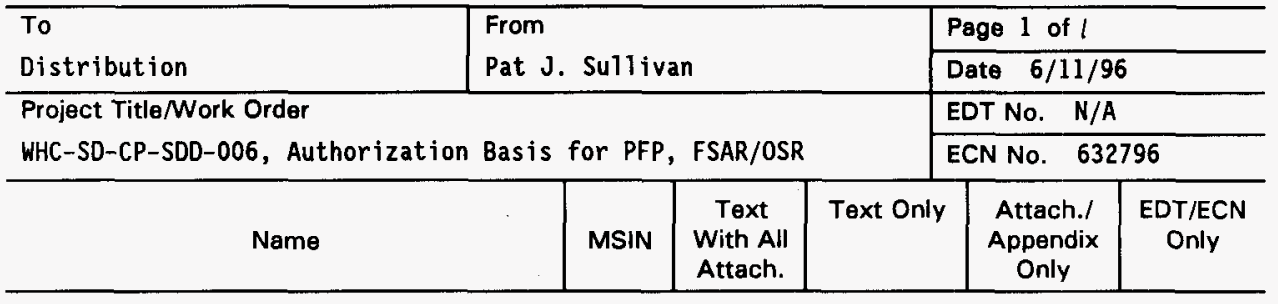

C. R. Allen III

G. G. Bergquist

R. Bocanegra J.W. Todd

B. M. Butts

J. M. Carey

J. D. Dick

L. E. Edvalson

M. W. Gibson

G. A. Glover

D. R. Groth

E. E. Icayan

J. P. King

C. M. Kronvall

E. M. LaRock

D. J. McBride

C. A. Meldrom

S. B. Merrick

S. E. Nunn

L. T. Nirider

R. D. Redekopp

H. E. Rew

L. H. Rodgers

W. D. Seaborg

P. J. Sullivan

R. W. Szempruch

M. D. Talbot

D. W. Templeton

C. P. Toreliti

P. K. Vacca

E. C. Vogt

$\begin{array}{ll}\text { T4 }-20 & x \\ \text { T5-55 } & x \\ \text { T5-50 R3-78 } & x \\ \text { T5-54 } & x \\ \text { T5-48 } & x \\ \text { T4-20 } & x \\ \text { T5-48 } & x \\ \text { T5-55 } & x \\ \text { T4-20 } & x \\ \text { T4-15 } & x \\ \text { T4-20 } & x \\ \text { T5-51 } & x \\ \text { T5-53 } & x \\ \text { T5-02 } & x \\ \text { T5-54 } & x \\ \text { T5-02 } & x \\ \text { T4-20 } & x \\ \text { T5-11 } & x \\ \text { T5-53 } & x \\ \text { T5-15 } & x \\ \text { T4-15 } & x \\ \text { T5-54 } & x \\ \text { T5-50 } & x \\ \text { T5-54 } & x \\ \text { T5-48 } & x \\ \text { T5-15 } & x \\ \text { R3 }-79 & x \\ \text { T5-52 } & x \\ \text { T5-51 } \\ \text { T5-50 } & x \\ & x\end{array}$

